\title{
Informatics Engineering Students' Competence in English: Formative and Summative Assessment
}

\author{
Andi Idayani \\ Universitas Islam Riau \\ E-mail: andiidayani@edu.uir.ac.id
}

\begin{abstract}
Assessment is the ways of teachers/lecturers gather data about their teaching and their students' learning. In order to grapple with what seems to be an over use of testing, educators should frame their view of testing as assessment and that assessment is information. In relation to this, the researcher interested in conducting a study which is focus on assessing Informatics Engineering students' competence in English. The researcher used descriptive research. The population of the reaserch was the informatics Engineering students which total students was 160 students at the second semester. Purposive sampling used in this study in order to focus the finding which the number of sample was 40 students. This study used formative and summative assessment in assessing students' comptence in English. Following that, the data was collected during teaching and learning process in form of observation, documentation, and test. After that, the data was analyzed by using statistical in term of norm-references and criterionreferences. Based on the result of this study, it could be concluded that the formative assessment format mostly designed in speaking and listening test format and summative assessment was applied all in English skills format since the lecturer consider that it is beneficial for students to master the particular skills as the requirements for applying into their careers.
\end{abstract}

Keywords: formative assessment, summative assessment, informatics engineering

\section{Kompetensi Bahasa Inggris Mahasiswa Teknik Informatika: Penilaian Formatif dan Summatif}

\begin{abstract}
Abstrak
Penilaian adalah cara guru/dosen mengumpulkan data tentang pengajaran dan pembelajaran siswanya. Untuk mengetahui hasil pembelajaran, maka pendidik menggunakan tes sebagai bentuk penilaian dan informasi bagi pendidik. Berkaitan dengan hal tersebut, peneliti melakukan penelitian yang difokuskan pada penilaian kompetensi Bahasa Inggris mahasiswa Teknik Informatika. Dalam penelitian ini, peneliti menggunakan penelitian deskriptif. Populasi penelitian ini adalah mahasiswa Teknik Informatika yang berjumlah 160 mahasiswa semester 2. Purposive sampling digunakan dalam penelitian dengan jumlah sampel 40 siswa. Penelitian ini menggunakan penilaian formatif dan sumatif dalam menilai kompetensi siswa dalam bahasa Inggris. Kemudian, pengumpulan data dilakukan selama proses belajar mengajar berupa observasi, dokumentasi, dan tes. Setelah itu, data dianalisis dengan
\end{abstract}


menggunakan statistik berupa acuan norma dan acuan kriteria. Berdasarkan hasil penelitian dapat disimpulkan bahwa format asesmen formatif sebagian besar dirancang dalam format tes berbicara dan menyimak dan asesmen sumatif diterapkan seluruhnya dalam format kecakapan bahasa Inggris karena bermanfaat bagi mahasiswa untuk menguasai kecakapan tertentu sebagai persyaratan untuk karir mereka.

Kata kunci: penilaian formatif, penilaian sumatif, teknik informatika

\section{INTRODUCTION}

Nowadays, English has become more dominant around the world including in Indonesia, and English subject is taught in every level of education start from primary school up to university level. Moreover, we can see that people now use English in various fields of life such as science, technology, sport, music, etc. Consequently, good mastery of English can help us to get a lot of information and keep in touch with people from different countries in the world. Besides that, in our life there are so many books and sources that also using English. Therefore, indirectly mastery English can help us to get and give a lot of necessary information each other especially for the students.

In higher education, English for Specific Purposes focus on the students need related to their field. Then, The ESP focal point is that English is not taught as a subject separated from the students' real world, instead, it is integrated into a subject matter area important to the learners. Therefore, it is necessary for teachers to prepare teaching materials based on the students' need.

Challenging while teaching in ESP class, of course, faced by teachers because they also need to master the technical terms of English based on the major that they will teach in ESP class. Following that, teachers have to motivate the students to keen on English. Enhancing students' ability in English is necessary in order to build up their competence in English. As we know that, the students need this ability to compete while they are seeking jobs.

The role of teachers plays an important point to develop the students' competence in English. Relation to this, the teachers need to master the material or topic to be discuss in a classroom. In addition, designing proper assessment for English for Specific Purposes' students are also vital in order to advance their skills in English.

According to Kibble (2017) said that both summative and formative testing have significant implications on student learning, and considerable consideration should be given to their selection and implementation. Summative evaluation is an age-old principle that promotes learning since most college students will think hard about methods to optimize success. On the other hand, we should not undervalue the importance of formative assessment, particularly in light of new evidence of how well the "testing effect" improves learning and memory when compared to alternative study techniques.

A good assessment program is one that matches the purpose and type of the assessment to the decisions made and the curriculum adopted (Brown, 2012), one that, consequently, adopts a 
good balance between formative and summative assessment, perhaps with more emphasis on the formative than the summative.

We believe that assessments for meaningful learning should provide students with the training, skills, and passion they need to succeed in the long run, not merely to obtain excellent grades and satisfy the criteria of a given course. As postsecondary and professional education shifts to competency-based models, it's becoming obvious that merely grading students on their performance during a certain period of time or in a specific course isn't enough. Meaningful learning and evaluation means aligning with meaningful outcomes for the next step of a learner's development, whether it's additional training or job learning (Kulasegaram K, \& Rangachari $\mathrm{P}$. 2018).

There are many classroom instructional strategies that are part of the repertoire of good teaching. When teachers use sound instructional practice for the purpose of gathering information on student learning, they are applying this information in a formative way. In this sense, formative assessment is pedagogy and clearly cannot be separated from instruction. It is what good teachers do. In contrast, teachers also need to do summative assessment to evaluate students' performance. Therefore, both of assessments are necessary to be implemented in a classroom. Finally, this study presents the discussion related to Informatics Engineering students' competence in English and the factors that the teacher considers in designing the formative and summative assessment.

The significance of this study can be viewed from both theoretical and practical aspects. In theoretically, it is expected that this study can be used as emphasis to determine the types of assessment that appropriate for students. While, in practically, it is expected to give positive input to the English teacher in teaching English, espeacially ESP classroom.

\section{Related Literature}

The term "specific" in ESP refers to the specific purpose for learning English. Students approach the study of English through a field that is already known and relevant to them. This means that they are able to use what they learn in the ESP classroom right away in their work and studies. The ESP approach enhances the relevance of what the students are learning and enables them to use the English they know to learn even more English, since their interest in their field will motivate them to interact with speakers and texts.

In general, English for specialized purposes differs from general English in terms of both the students' backgrounds and the goal of education. In reality, whereas in ESL all four language skills are equally emphasized, in ESP a requirements analysis determines which language abilities are most needed by the students, and the syllabus is developed appropriately. For example, an ESP program may stress the development of reading abilities in students preparing for graduate studies in the technology sector, while it might encourage the development of speaking skills in students learning English to become tour guides.

$\mathrm{ESP}$, in reality, integrates topic content with English language instruction. Students may apply what 
they learn in English classes to their major subject of study, whether it's accounting, business management, economics, computer science, or engineering, which is a very stimulating mix. The ability to apply what they've learned in terms of language and structures in a relevant situation reinforces what they've learned and boosts their drive.

Students' abilities in their respective disciplines increase their capacity to learn English as a result. Subject-matter expertise provides individuals with the context they need to comprehend classroom English. Students in the ESP program are taught how to convey subject area knowledge in English. The instructor may make the most of the students' subject-matter expertise, therefore assisting them.

\section{The Importance of English for Specific} Purposes

A teacher with prior expertise teaching English as a Second Language (ESL) can take advantage of her previous language teaching experience. She should be aware of how her teaching abilities may be applied to the teaching of English for Specific Purposes. She also needs to seek out topic specialists for assistance in developing acceptable courses in the subject area. She has a lot of hats to wear as an ESP instructor. Teachers may be expected to plan classes, develop learning objectives, create a pleasant learning atmosphere in the classroom, and assess students' progress.

Teachers must create learning goals before converting it into an educational program with activity scheduling in Organizing Classes. One of the major responsibilities will be to pick, develop, and organize course materials, as well as to encourage students in their efforts and provide comments on their progress.

Teachers create long-term goals and short-term objectives for students' achievement during Setting Goals and Objectives. Teachers' understanding of students' potential is crucial in developing a syllabus with realistic goals that considers students' concerns in the classroom.

The following step is to create a learning environment. The classroom atmosphere is created by the instructors' communication and mediation abilities. When students have opportunities to communicate with other speakers in the language, they learn it. They may be the sole English speakers available to students due to their position as teachers, despite the fact that they have limited time with them, they can structure excellent communication skills in the classroom. To do so, instructors should strive to listen closely to what students are saying and reflect their comprehension or misunderstanding back to them through teacher responses.

Good language learners are also strong risk-takers, as they must make a lot of mistakes to succeed; yet, they are disadvantaged in ESP programs because they are unable to leverage their native language proficiency to present themselves as well-informed adults. As a result, the instructor should foster a supportive environment in the language classroom. Learners must be selfassured in order to communicate, and it is your duty to assist them in developing that confidence.

Finally, there is Evaluating Students. The instructor is a resource who assists students in identifying and solving language learning difficulties, 
determining the skills they need to focus on, and taking responsibility for making decisions about what and how they learn. Teachers will provide students with information on how they are developing in their language study.

\section{Strategies for Teaching ESP Class}

When people have opportunity to study and work with language in a setting that they understand and find fascinating, they learn languages. ESP, in my perspective, is a strong tool for creating such possibilities. Students will learn English while they engage with things that are fascinating and relevant to them and that they can apply to their professional career or future education. The less they are motivated to attend their lessons, the more they must concentrate on linguistic input or isolated language structures.

In the subject-matter field, the ESP student is more prone to focusing on meaning. English should not be taught in ESP as a topic to be learnt apart from real-world application, nor as a mechanical talent or habit to be acquired. English, on the other hand, should be given in genuine settings to familiarize learners with the specific ways in which the language is employed in activities that they will be required to execute in their fields of expertise or employment.

\section{Subject-Content Knowledge}

Learners in ESP lessons are typically aware of the objectives for which English will be required. They consider their English instruction as complimenting their schooling, which they have previously focused on a certain subject. Students can recognize a real context for the ESP classroom terminology and structures if they have knowledge of the topic area. As a result, learners may use what they already know about the subject to help them learn English.

\section{Learning Strategies}

Adults must put in more effort than children to learn a new language, but the learning skills they bring to the endeavor enable them to learn more quickly and effectively. Learning English will be easier for them because of the abilities they have previously established in their original languages. Despite the fact that teachers will be working with students whose English skills are likely to be inadequate, the adult in the ESP classroom has enormous language learning potential. Because language acquisition occurs organically throughout our lives, educated individuals are always acquiring new language behaviors in their home languages. They are continuously growing their vocabulary, gaining fluency in their professions, and adapting their linguistic behavior to new situations or positions. These natural abilities can be used by ESP students to learn English.

\section{Formative Assessment}

Formative Assessment is a part of the instructional process. When incorporated into classroom practice, it provides the information needed to adjust teaching and learning while they are happening. In this sense, formative assessment informs both teachers and students about student understanding at a point when timely adjustments can be made. These adjustments help to ensure students achieve targeted standardsbased learning goals within a set time frame. Although formative assessment strategies appear in a variety of formats, 
there are some distinct ways to distinguish them from summative assessments (Brown and Abeywickrama, 2019).

The goal of formative assessment is to monitor student learning to provide ongoing feedback that can be used by instructors to improve their teaching and by students to improve their learning. More specifically, formative assessments:

1. Help students identify their strengths and weaknesses and target areas that need work

2. Help faculty recognize where students are struggling and address problems immediately

Formative assessments are generally low stakes, which means that they have low or no point value. Examples of formative assessments include asking students to:

1. Draw a concept map in class to represent their understanding of a topic

2. Submit one or two sentences identifying the main point of a lecture

3. Turn in a research proposal for early feedback

\section{Summative Assessment}

Summative Assessments are given periodically to determine at a particular point in time what students know and do not know. Many associate summative assessments only with standardized tests such as state assessments, but they are also used at and are an important part of district and classroom programs. Summative assessment at the district/classroom level is an accountability measure that is generally used as part of the grading process. For examples, district benchmark or interim assessments, End- of-unit or chapter tests, End-of-term or semester exams. Scores that are used for accountability for schools (AYP) and students (report card grades).

The key is to think of summative assessment as a means to gauge, at a particular point in time, student learning relative to content standards. Although the information that is gleaned from this type of assessment is important, it can only help in evaluating certain aspects of the learning process. Because they are spread out and occur after instruction every few weeks, months, or once a year, summative assessments are tools to help evaluate the effectiveness of programs, school improvement goals, alignment of curriculum, or student placement in specific programs. Summative assessments happen too far down the learning path to provide information at the classroom level and to make instructional adjustments and interventions during the learning process..

The goal of summative assessment is to evaluate student learning at the end of an instructional unit by comparing it against some standard or benchmark. Summative assessments are often high stakes, which means that they have a high point value. Examples of summative assessments include: a midterm exam, a final project, a paper, a senior recital. Information from summative assessments can be used formatively when students or faculty use it to guide their efforts and activities in subsequent courses.

\section{METHOD}

According to Creswell (2012), the researcher utilized a quantitative method to establish a research topic 
based on patterns in the area or the desire to explain why something happens. Descriptive research can be done in the laboratory, in the class and in the field. In this study, the descriptive research is done in the class with taking students as the sample. This research was conducted at Informatics Engineering Faculty of UIR. The participants were students at the second semester of Informatics Engineering. The researcher chooses 2D class as the sample. Therefore, the total sample of this research was 40 students.

In this study, the instrument was documentation, observation, and test. A test is a set of stimuli presented to an individual in order to elicit responses. According to those statements, test document is the document shows the result of a test, which represented the students' measurement as a response of stimulus.

The researcher collected the data which need to support this reasearch. The data was colleted during teaching and learning process in term of documentation, students' assignments, students' quiz, presentation, group discussion, mid and final test. Then, the data was analyzed based on the students' performance, students' assignments, students' quiz, presentation, group discussion, mid and final test that interpreted both in qualitative and quantitative approach.

\section{FINDING AND DISCUSSION}

The researcher presents the data of Informatics Engineering Students' Competence in English: Formative and Summative Assessment. In this study, the researcher assessed the students' competence by doing test, observation, and documentation. The results of this study reveal some information regarding the two questions of this study, which are (1) What is Informatics Engineering students' competence in English? (2) What factors does the lecturer consider in designing the formative and summative assessment?

\section{Formative and Summative Assessments}

In this study, the reseacher applied formative and summative assessment. It could be explained in the following discussion.

\section{Table 1. Formative and Summative} Assessments

\begin{tabular}{|c|c|}
\hline Meeting & Topics and Assessment \\
\hline \multirow[t]{6}{*}{$1-2$} & Topic: \\
\hline & Learning Contract and \\
\hline & Introducing yourself \\
\hline & Assessment: \\
\hline & Formative Assessment (student \\
\hline & $\begin{array}{l}\text { introduced her/himself in front of the } \\
\text { classroom. }\end{array}$ \\
\hline \multirow[t]{4}{*}{3} & Topic: Types of Jobs in IT \\
\hline & Assessment: \\
\hline & Formative assessment (students \\
\hline & $\begin{array}{l}\text { explained by giving the reason about } \\
\text { students' dream job in IT) }\end{array}$ \\
\hline \multirow[t]{5}{*}{4} & Topic: The World Wide Web \\
\hline & Assessment: \\
\hline & Formative assessment (students \\
\hline & listened the video from you-tube \\
\hline & $\begin{array}{l}\text { about world wide web and after that } \\
\text { the students wrote what they have } \\
\text { listened). }\end{array}$ \\
\hline \multirow[t]{3}{*}{5} & Topic: Emailing \\
\hline & Assessment: \\
\hline & $\begin{array}{l}\text { Formative assessment (student wrote } \\
\text { an email, informed the IT's products } \\
\text { by comparing them). }\end{array}$ \\
\hline \multirow[t]{6}{*}{6} & Topic: Features of Good Websites \\
\hline & Assessment: \\
\hline & Formative assessment (students \\
\hline & worked in a group about the features \\
\hline & of good websites that they have \\
\hline & $\begin{array}{l}\text { chosen and continued to discussed } \\
\text { with others groups). }\end{array}$ \\
\hline \multirow[t]{3}{*}{7} & Topic: Domain \\
\hline & Assessment: \\
\hline & $\begin{array}{l}\text { Formative Assessment (students read } \\
\text { an article "master your domain" and } \\
\text { wrote the summary). }\end{array}$ \\
\hline \multirow[t]{2}{*}{8} & Topic: Mid-test \\
\hline & Assessment: summative assessment \\
\hline
\end{tabular}




\begin{tabular}{cl}
\hline 9 & Topic: Computer Users \\
& Assessment: \\
& Formative assessment (group \\
& discussions about computer users) \\
& Topic: Application Program \\
& Assessment: \\
& Summative Assessment (students \\
& made a project of application \\
& program and presented the last \\
& meeting). \\
& Topic: Computing Support Officer \\
& Assessment: \\
& Formative assessment (students read \\
& the articles by scanning and \\
& skimming). \\
& Topic: Networks \\
& Assessment: \\
& Formative assessment (students \\
practiced "asking and giving \\
opinion" with the current issues of \\
networks) \\
Topic: IT Support \\
Assessment: \\
Formative assessment (students \\
wrote a descriptive text). \\
Topic: Workstation health and safety \\
Assessment: \\
Formative assessment (group \\
discussion) \\
Topic: Data security \\
Assessment: \\
Formative assessment (students \\
listened to the video about data \\
security). \\
Topic: Final-test \\
Assessment: summative assessment \\
\hline
\end{tabular}

According to the assessments which are summarized and displayed on the table 1, it has been indicated that there are two kinds of assessment formats which applied in the class. First is the formative assessment and second is summative assessment. While other assessment for listening and reading are also implemented during teaching and learning process.

Allocating more speaking skills in the assessment in ESP class has been investigated start from at the beginning of meeting until at the last meeting. Not only from the lecturer's perspective, but also the students agree that the continuous assessment which provides more speaking skills format is helpful for their learning. Besides speaking format which takes more than $70 \%$ part in the assessment, recapping all types of materials is dominated by the percentage of $30 \%$. The data is also reflected in this research through the writing test format as an instrument for recapping the materials involving others integrated skills.

Designing the assessment into several particular formats which is not following the general/ traditional format is related to the notion of alternative assessment. As mentioned by AlMahrooqi and Denman (2018) state that alternative assessment is a catch-all phrase for a variety of non-traditional or conventional assessment methods. In addition, Alternative assessment includes a variety of tasks that challenge learners to apply high-level thinking abilities in real-world circumstances or in genuine contexts (Al Ruqeishi, 2015).

However, the lecturer's idea of regularly giving speaking skills and writing skill format assessment and sometimes listening and reading skill during the formative assessment in order to progressively train the students to be familiar with those chosen format is supported by the formative assessment function mentioned by Strijbos and Sluijsmans (2010). They describe that Formative assessment is "contextualized" and attempts to provide a "complete picture" of the qualities of the students. It is an important element of the learning process and occurs multiple times during a course rather than just at the conclusion.' In the meantime, summative assessment as a measurement which takes place to round things off or make a one-off measurement is represented by the 
lecturer through all english skill format as an integrated skills assessment format.

In designing the assessment, the lecturer previously hold a discussion with all the related personnel, such as the other lecturers and students. All the perspectives are considered as the basis for the assessment design. The discussion came out with the notion of the importance of speaking for communication. Besides the importance of speaking skills for getting involved with the personnel in the workplace, writing format assessment is considered crucial to learn since most of companies require the future employees not only be able to speak English but also can write in English. Hence, the students are expected to be more familiar with speaking activities and writing form as the preparation for seeking job at a company. Thus, the lecturer decides to design the formative assessment with more portion of speaking format and combine the other integrated skills, while the summative assessment is all in English format. The design is referred to all the course needed and presented to the students.

This explanation shows the importance of all the involved personnel to take part and play they role in developing a better assessment for the students in ESP class. The initiative of each person to contribute or give opinion and experienced insight significantly helps the lecturer to design an appropriate assessment for the students.

\subsection{The Informatics Engineering Students' Competence in English}

The lecturer has taught four classes in informatics Engineering field, particularly at the second semester of Informatics Engineering students which consist of 40 students for each classes in academic year 2018/2019 and II D was chosen as sample of this study.

However, after the learning process have done, the lecturer has calculated the students' score based on students' performance in class, students' assignments, final project, mid and final semester test that were classified as formative and summative assessements. The figure below shows the students' scores during one semester.

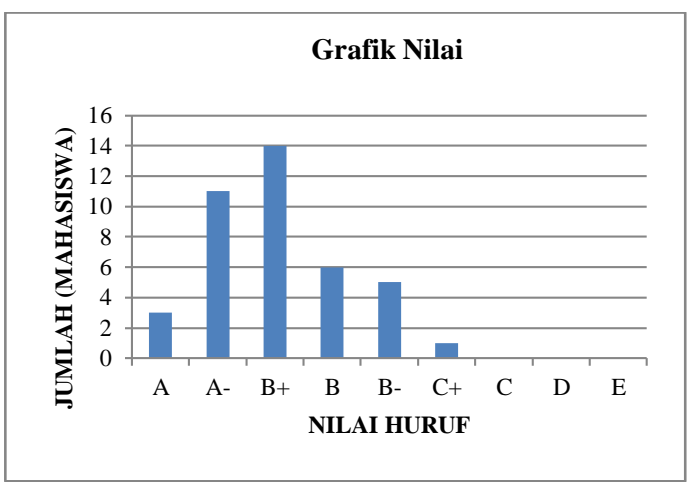

Figure 1. The Students' Score

Based on the Figure1, it can be seen that the majority of students got A- (11 students) and $\mathrm{B}+$ (14 students), while only 1 student got $\mathrm{C}+$. Then, some of them got A (3 students), B (6 students), and B- (5 students). Therefore, it can be concluded that most of students in Informatics engineering subject have a good competence in English.

\begin{tabular}{ccccc}
\multicolumn{3}{c}{ Table 2. The Students' Classification } \\
\hline No & Categories & Score & $\begin{array}{c}\text { Frequ } \\
\text { ency }\end{array}$ & $\begin{array}{c}\text { Percen } \\
\text { tage }\end{array}$ \\
\hline 1. & $\begin{array}{c}\text { Good to } \\
\text { Excellent }\end{array}$ & $\begin{array}{c}80- \\
100\end{array}$ & 27 & $67.50 \%$ \\
2. & $\begin{array}{c}\text { Average to } \\
\text { Good }\end{array}$ & $66-79$ & 13 & $32.50 \%$ \\
\hline
\end{tabular}




\begin{tabular}{ccccc}
\hline 3. & Poor to & $56-65$ & 0 & $0 \%$ \\
& Average & & & \\
4. & Poor & $40-55$ & 0 & $0 \%$ \\
& Total & & $\mathbf{4 0}$ & $\mathbf{1 0 0 \%}$ \\
\hline
\end{tabular}

Referring to the Table 2 illustrated above, it can be seen that there were 27 students got score (80$100)$ and categorized as "good to excellent". While, only 13 students got score (66-79) and categorized as "Average to Good", and no students were categorized as poor to average and poor. However, the majority of the Informatics engineering students' in English were classified into "good to excellent" category.

Factors that the lecturer consider in designing the formative and summative assessment.

It is necessary to begin the evaluation process by analyzing the target population of students: Many issues in L2 classrooms arise as a consequence of educators failing to pay attention to students' interests and dismissing them as a source of primary knowledge.

The availability of instructional resources is a deciding factor for many instructors and lecturers. Furthermore, the course's content is determined by the materials used. It is frequently used to justify and explain the usage of the same curriculum with diverse students. The appropriateness of materials in student-centered education involves student comfort and familiarity with the content, language level, interest, and relevance. It will, however, be reflected in the sorts of assessments that are created.

There are four factors mentioned by the lecturer as the consideration in designing assessment for informatics engineering class:

a. Relevance.

When taking into account information about the students, goals, and objectives, teachers need to determine which aspects of ESP learning will be included, emphasized, integrated, and used as a core of the course to address students' needs and expectations. Therefore, all components should be relevance with the students' need. Lecturer has focused on developing basic skills and communicative competence. It should also be obvious that, although being separated in structural diagrams, all abilities and features of the language are intertwined in real-life communication. Therefore, they should be treated, taught, and tested in form of assessment.

\section{b. Innovative and Efficient}

Based on the explanation of relevance, innovative and efficient given by the lecturer, those three factors generally represent the factor of need analysis. Padilla, Joan (2016) mentions that in order to fulfilled the learners' specified needs, ESP practitioners must analyze their needs, create a course, produce materials, select appropriate training, and apply it. As a result, an ESP instructor must have more than just a basic understanding of the language system and the capacity to communicate it. However, they should have capability to design appropriate assessment to their students. It is important to have a well-designed assessment which can measure all the aspects 
expected from the students within the limited time given in the class during the semester.

c. Convenient in terms of expenses The expenses spent for the assessment should not exceed the allocated budget. It is common that there will be expenses spent through the course, included the assessment. It is crucial for the lecturer to manage the course and assessment expenses to be sufficient based on the budget existed.

\section{d. Communicative}

As the main goal of language learning, communication is a compulsory aspect to be measured in an assessment. Students need to be exposed into the communicative environment as well as the communicative type of assessment so that they can practice and eventually acquire the communicative competence as stated by Thabit (2018). Specifically, having the ability to communicate is defined as communicative competence. This skill can be expresses verbally, in writing, or even nonverbally. It is a broad word that relates to both language knowledge and the ability to utilize the language in real-life circumstances.

The last three points of factors taken in designing assessment are clearly required for all kinds of assessments since it is more related to technical aspects which determine whether or not the assessment will run properly.

\section{CONCLUSION}

Based on the result of this study, it could be concluded that the formative assessment format mostly designed in speaking and writing test format and summative assessment is all in English skill format since the lecturee consider that it is beneficial for students to master the particular skills as the requirements for applying into their careers.

The formative and summative assessment is designed based on the perspective or opinion gathered from the related personnel such as the other instructors, and students to gain deeper insight on what is crucial to measure from the students related to the course objectives.

In assessing the students competence in English, the lecturer have already applied the formative and summative assessment. In general, the informatics engineering students have good to execellent category in English. Most of them can past all kinds of assessment that given from the lecturer. Only one student got low score compared to others.

There are some factors considered by the lecturer in designing the assessments, which are; relevance, innovative and efficient, convenience for the budget, and communicative.

In this study, the researcher would like to give some suggestions for the teacher, students and for the next researcher.

a. The Teacher/lecturer

It is recommended to all the related personnel to take advantage of the findings of this research to design, expand, and support the development of assessment in ESP class since it requires different approach compared to assessment for general class. 
For the lecturer, it is expected to acknowledge the special needs of students in ESP class in terms of creating the assessment since the outcome will be directly reflected on the students' skills or performance.

b. The student

The students need to contemplate on their objectives for taking the particular course and actively contribute in suggesting the teacher's design on their activities, including the assessment in the course.

Finally, it is strongly expected that the stakeholder gives their full support for the researcher for designing a particular assessment, formative and summative, to fulfill the special requirement of ESP class (informatics engineering filed).

\section{REFERENCES}

Al-Mahrooqi, R., \& Denman, C. (2018). Alternative Assessment. The TESOL Encyclopedia of English Language Teaching, 1-6.

Brown, J.D. (2012). Choosing the right kind of assessment. In C. Coombe, P. Davidson, B.O'Sullivan,\& S. Stoynoff (Eds.), The Cambridge Guide to Second Language Assessment (pp. 105-12). New York, NY: Cambridge University Press.

Brown, H. D., \& Abeywickrama. (2019). Language Assessment Principles and Classroom Practices $3^{\text {rd }}$ Edition. Pearson Education ESL.

Creswell, John W. (2012). Educational research: planning, conducting, evaluating, quantitative and qualitative research (Fourth Edition). United State of America: Pearson Education Inc.
Kibble JD. (2017) Best practices in summative assessment. $A d v$ Physiol Educ 41: 110-119, 2017. doi:10.1152/advan.00116.2016.

Kulasegaram K., \& Rangachari P. (2018) Beyond "formative": assessments to enrich student learning. Adv Physiol Educ 42: 514 , 2018 doi:10.1152/advan.00122.2017.

Padilla, Joan. (2016). Principles of ESP. Scribd, https://www.scribd.com/document /322743689/Principles-of-Esp.

Strijbos, J. W., and D. M. A. Sluijsmans. 2010. "Unravelling Peer Assessment: Methodological, Functional, and Conceptual Developments." Learning and Instruction 20: 265-

269.10.1016/j.learninstruc.2009.0 8.002 .

Thabit Ahmed, Sabri. (2018). Communicative competence in English as a Foreign Language: Its Meaning and the Pedagogical Considerations for its Development, Munich, GRIN Verlag, https://www.grin.com/document/4 32042 . 